\title{
Resenhas
}

\section{Textos Informativos: AuxílIo Eficaz no Jardim 3}

\section{Kletzien, S. B.; Dreher, M. J. 2004. Informational Text in K-3 Classrooms. Helping Children Read and Write. Newark : Reading Association. $160 \mathrm{pp}$.}

A leitura e a escrita têm seu papel fundamental na formação do cidadão, pois é o veículo primordial para que possa atingir sua plenitude. Essa leitura e escrita devem ser incentivadas e orientadas desde que a criança tenha suas primeiras experiências com elas.

Há que se considerar que a interação professor-aluno na relação ensino-aprendizagem é ponto importante, porque ela propiciará uma identificação de habilidades, do estilo cognitivo e de aprendizagem do aluno, adaptando-o aos objetivos educacionais e metodológicos, entre outros aspectos. Isso justifica a preocupação dos estudiosos com a maneira pela qual ocorre desde a préescola tendo em vista a formação de leitores/escritores e a este ponto as autoras afirmam que "revistas infantis que possuam textos informativos auxiliam a estender $o$ conhecimento de mundo da criança" ( p. 21).

Assim, no livro Informational Text in $K-3$ Classrooms, helping children read and write as autoras Sharon Benge Kletzien e Mariam Jean Dreher mostram-nos o quanto é importante para a formação das crianças a inclusão de textos informativos tanto para a leitura quanto para a escrita, porque são eles que têm o propósito de informar ou persuadir a audiência. Como exemplo, têm-se as notícias, biografias, autobiografias, histórias, livros de textos, revistas e jornais.

Ao longo da leitura do livro é possível perceber, em seus oito capítulos, três apêndices e referências bibliográficas, o importantíssimo papel atribuído ao professor para a implantação desses recursos no contexto educacional.

No primeiro capítulo, as autoras mostram que ainda persiste a ênfase no uso de histórias para instruções e alfabetização das séries primárias, apesar de muitos estudiosos incentivarem tais professores a utilizarem mais textos informativos em sala de aula para que as crianças estejam aptas a descobrir, entender, avaliar e sistematizar informações por meio de suas variadas fontes. A relutância desses professores na utilização de textos informativos está na falta de confiança que sentem para elaborar lições apropriadas aos textos informativos.

A inclusão de textos informativos na biblioteca da classe é o assunto do segundo capítulo no qual Kletzien e Dreher salientam que, com a criação de uma biblioteca em sala de aula, há um acesso fácil a livros e outros materiais escritos, o que pode ajudar as crianças a se tornarem leitores motivados e habilidosos. Também apontam para a importância de os textos informativos que possibilitam proporções para a exposição escrita, pois, geralmente, as crianças das séries iniciais são menos expostas a esse tipo de texto escrito do que o são às formas narrativas. Quanto ao uso da biblioteca comentam que "sem o apoio dos professores que apresentam materiais e livros à rotina diária dos alunos, os fatores físicos, por si só, não terão sucesso" (p. 26). Dessa forma, nota-se a importância do professor, principalmente nas séries iniciais para a orientação na escolha do material, ordenação e método de leitura.

$\mathrm{O}$ mercado tem disponibilizado livros informativos muito bons para uso dos professores, porém sua escolha para possível inclusão na biblioteca da classe para leitura e outras atividades deve ser feita com cuidado. Um planejamento adequado pode resultar em sucesso pelo uso desses livros informativos. Para tanto, deve-se escolher o livro adequado a cada faixa etária da criança. Outro ponto salientado pelas autoras é a importância das ilustrações que podem ser fotografias, diagramas, mapas, desenhos, cartas ou figuras que representam uma forma de acrescentar esclarecimento à informação e estender o texto. Porém, deve haver uma boa organização na escolha desses livros, tendo cuidados e utilizando-se critérios tais como observar nos textos as causas/efeitos, comparações/contrates, seqüências, perguntas/respostas, descrições e generalizações/exemplos. Todos esses aspectos relevantes justificam o tema tratado no terceiro capítulo, que é a escolha de livros informativos para uso em sala de aula. 
As informações trazidas no quarto capítulo pelas autoras, a respeito do uso dos livros informativos para leitura em voz alta mostram-nos que pesquisas feitas provam que a leitura em voz alta é de extrema importância e valor para a motivação e o desenvolvimento da criança. Os professores precisam ser incentivados para que leiam bons livros a seus alunos, regularmente e em voz alta. Embora muitas pesquisas e mesmo a tradição apoiem a leitura de ficção, a inclusão de textos informativos nessa categoria é de substancial importância para que o aluno tenha uma visão mais ampla e rica do que ocorre no mundo, inspira a curiosidade e o aprendizado, além de se tornar um veículo para o ensino das estratégias de compreensão e conhecimento de mundo. As autoras dão como exemplo a elaboração de uma ficha de leitura, na qual os alunos anotam a data do material, o autor, o título, tipo de livro e informações adicionais - ficção ou não, exposição de informações, etc. (p.131) .

Um desafio da escola é formar leitores estratégicos e isto implica numa perfeita compreensão do que foi lido, a este ponto Kletzien e Dreher apontam o ensino de estratégias de compreensão pelo uso de textos informativos como um dos pilares da leitura dos textos informativos. Essas estratégias de compreensão podem ser desenvolvidas antes da leitura (acessando conhecimentos anteriores sobre o assunto), durante a leitura (fazendo conexões, questionamentos, inferências, parafraseando, etc.) e após a leitura (sumarizando ou criando gravuras ou gráficos). Para essas estratégias pode-se utilizar a técnica de leitura em voz alta com orientações para grupos grandes ou pequenos, pois o objetivo, segundo as autoras, é fazer com que a criança se torne um leitor capaz de orquestrar um determinado número de estratégias de compreensão para seu próprio uso e sucesso.

Atualmente, com a inserção da tecnologia da informação, a escola enfrenta um sério problema: como trabalhar com ela? A esse questionamento, as autoras dão orientações e ensinam como as crianças devem encontrar informações tanto em livros quanto na internet, pois espera-se que elas sejam "letradas na informação". Com a busca de informações em contextos significativos e com propósitos reais, os professores podem ajudá-las a se tornar proficientes em informação. Outro ponto salientado pelas autoras é quanto à utilização das informações pesquisadas em livros e websites, seu monitoramento na busca, avaliação, anotação e organização. A esse ponto o professor tem um papel fundamental, já a partir da pré-escola.
As autoras, no sétimo capítulo, salientam que a leitura e a escrita se desenvolvem juntas. Ao ensinar as crianças a escreverem textos informativos, elas apontam a eficiência da leitura de diferentes textos informativos para a formação de um bom escritor, utilizando-se das mesmas formas, pois quando têm a oportunidade e encorajamento, elas escreverão textos com estruturas similares aos textos lidos. Para tanto há necessidade de que as crianças tenham contato com muitos exemplos de formas diferentes de escrituração e identificar as características do texto tais como relatórios, descrições, histórias em quadrinhos, resumos, poesias, etc. e também saberem partilhar tais informações.

No último e oitavo capítulo, as autoras apresentam considerações finais com o nome Put It All Together (Colocando tudo junto). Apontam a necessidade de existirem fortes razões para que se mude a situação de ensino tradicional (crianças expostas quase que exclusivamente a histórias), uma delas é o de que as crianças vão encontrar outra expectativa pela frente. Além disso, os textos informativos compõem o que a maioria das crianças mais velhas e adultos lê e escreve; portanto faz sentido dar às crianças a chance de aprender mais do que estórias na escola. O outro ponto observado pelas autoras diz respeito aos dados consistentes que apoiam a idéia de que o desempenho dos alunos melhora com a oportunidade de ler e receber orientações sobre textos informativos.

Fechando o livro, há apêndices apresentando aos professores diversos recursos como nomes de revistas e jornais; websites para listas de livros informativos (com seus endereços e correios eletrônicos); planos de instrução de estratégias de leitura; tipos e características de escritas informativas. Também referências bibliográficas tanto para o professor quanto para o aluno.

Fica claro que a riqueza do livro permanece em explicitar e orientar que em educação sempre há alternativas para sua melhora, constituindo-se em um instrumento de informação útil para docentes, pesquisadores e todos aqueles que se interessam pelo assunto tratado, uma vez que traz para o contexto educacional a possibilidade de uma aproximação entre essas novas estratégias e o processo ensino-aprendizagem, viabilizando uma prática pedagógica renovada, um verdadeiro auxílio eficaz e que busca uma maior proximidade com as necessidades de formação do leitor-cidadão.

Elza Maria Tavares Silva Universidade de Mogi das Cruzes/SP 